\title{
Iodine in drinking water varies by more than 100-fold in Denmark. Importance for iodine content of infant formulas
}

\author{
K M Pedersen ${ }^{1}$, P Laurberg ${ }^{1}$, S Nøhr ${ }^{2}$, A Jørgensen ${ }^{2}$ and S Andersen ${ }^{1}$ \\ ${ }^{1}$ Department of Endocrinology and Medicine and ${ }^{2}$ Department of Obstetrics, Aalborg Hospital, Denmark \\ (Correspondence should be addressed to P Laurberg, Department of Endocrinology and Medicine, Aalborg Hospital, Reberbansgade, \\ DK 9000 Aalborg, Denmark)
}

\begin{abstract}
The iodine intake level of the population is of major importance for the occurrence of thyroid disorders in an area. The aim of the present study was to evaluate the importance of drinking water iodine content for the known regional differences in iodine intake in Denmark and for the iodine content of infant formulas.

Iodine in tap water obtained from 55 different locations in Denmark varied from $<1.0$ to $139 \mu \mathrm{g} / \mathrm{l}$. In general the iodine content was low in Jutland (median $4.1 \mu \mathrm{g} / \mathrm{l})$ with higher values on Sealand $(23 \mu \mathrm{g} / \mathrm{l})$ and other islands. Preparation of coffee or tea did not reduce the iodine content of tap water with a high initial iodine concentration. A statistically significant correlation was found between tap water iodine content today and the urinary iodine excretion measured in 41 towns in $1967(r=0.68$, $P<0.001)$. The correlation corresponded to a basic urinary iodine excretion in Denmark of $43 \mu \mathrm{g} / 24 \mathrm{~h}$ excluding iodine in water and a daily water intake of $1.7 \mathrm{l}$. The iodine content of infant formulas prepared by addition of demineralized water varied from 37 to $138 \mu \mathrm{g} / \mathrm{l}$ (median $57 \mu \mathrm{g} / \mathrm{l}, n=18$ ). Hence the final iodine content would depend heavily on the source of water used for preparation.

We found that iodine in tap water was a major determinant of regional differences in iodine intake in Denmark. Changes in water supply and possibly water purification methods may influence the population iodine intake level and the occurrence of thyroid disorders.
\end{abstract}

European Journal of Endocrinology 140 400-403

\section{Introduction}

In previous comparative epidemiological studies it has been found that the population iodine intake is of major importance for the occurrence of thyroid disorders in an area $(1,2)$. A relatively low iodine intake was accompanied by a high incidence of toxic multinodular goitre and a high prevalence of subclinical hyperthyroidism in elderly subjects. In a high iodine intake area the incidence of Graves' disease was high in the young and the middle aged, and subclinical hypothyroidism was common in the elderly.

The aim of the present study was to obtain more knowledge of the factors determining the population iodine intake. In Denmark several studies have demonstrated a higher iodine intake level in the eastern part of the country including Copenhagen compared with Jutland in the western part of the country $(3,4)$. Despite considerable alterations in transport of food this difference has been rather stable over many years (4). We therefore investigated the importance of differences in tap water iodine content for the known geographical variation in iodine intake. Practically all tap water used in Denmark is ground water, which is used for all purposes including drinking and preparation of food without restrictions. We also studied the importance of iodine in water for the iodine intake of infants fed infant formulas. It has been shown that many infant formulas are relatively low in iodine content (5).

\section{Materials and methods}

Tap water was collected in iodine-free plastic containers in laboratories at 55 different locations in Denmark. The samples were taken by laboratory staff and kept at $-20^{\circ} \mathrm{C}$ until analysis. Two samples were collected at each location with an interval of two months. In addition one sample was collected on the island of Læsø. To investigate day-to-day variations iodine was measured in samples collected on 10 consecutive days in Aalborg with low iodine content and Skagen with high iodine content of tap water. For comparison iodine was measured in samples of sea water collected at the east and the west coasts of North Jutland. The stability of iodine in water during preparation of coffee and tea was studied using water from the site with the highest iodine content of water. Coffee was prepared on a Melitta 161 
coffee machine using brown standard Melitta filters and vacuum packed coffee from Merrild, Denmark. Tea was prepared by a short boiling of the water followed by incubation of one tea bag in $200 \mathrm{ml}$ water for $3.5 \mathrm{~min}$. The tea was either Earl Grey or camomile tea. All procedures were performed in triplicate.

Twenty-two infant formulas from eight manufacturers were investigated. Four preparations were liquid ready for use, while eighteen were dry preparations. Demineralized water was added for the final preparation according to the manufacturers' instructions.

Iodine was measured by the method of Wilson and van $\mathrm{Zyl}$ (6) as previously described (7). The principle is alkaline incineration of the sample followed by measurement of iodine by the Ceri/As method. Using a $2 \mathrm{ml}$ sample the limit of detection was $1.0 \mu \mathrm{g} / \mathrm{l}$. The recovery of added iodine was $>95 \%$. All samples were measured in duplicate. For calculation of average iodine content samples measured to contain $<1.0 \mu \mathrm{g} / \mathrm{l}$ were arbitrarily given a value of $0.5 \mu \mathrm{g} / \mathrm{l}$.

Statistical evaluation of correlation and calculation of linear regression between tap water iodine content and previously published urinary iodine excretion values (Pearson), and comparison of median values (MannWhitney test) were performed using the Med Stat statistical program (Astra, Albertslund, Denmark).

\section{Results}

Considerable regional differences were found in iodine content of the tap water. In general the iodine content was low in Jutland $(4.1 \mu \mathrm{g} / \mathrm{l}(3.1-6.3)$ median, 95\% confidence of median) with higher values on Sealand $(23 \mu \mathrm{g} / \mathrm{l}(10.4-26.6))(P<0.01$ vs Jutland) and other islands. The median of all samples was $7.5 \mu \mathrm{g} / \mathrm{l}(95 \%$ confidence 4.7-14.0). The iodine values found at different sites were very similar when measured in two samples collected at two-month intervals: sample 2 as a percentage of sample 1: median 100.0\% (25-75\% interval $80.7-117.4 \%$ ). The day-to-day variation measured at two sites on 10 consecutive days varied little (Aalborg: 4.2-6.7 $\mu \mathrm{g} / \mathrm{l}$, median $5.6 \mu \mathrm{g} / \mathrm{l}$; Skagen: 138$151 \mu \mathrm{g} / \mathrm{l}$, median $144 \mu \mathrm{g} / \mathrm{l})$.

Preparation of coffee or tea using water from the site with the highest iodine content did not reduce the iodine content (water $146 \pm 2$, coffee $157 \pm 1$, Earl Grey tea $154 \pm 2$, camomile tea $157 \pm 2 \mu \mathrm{g} / \mathrm{l}$ (means \pm S.D., $n=3)$ ).

Figure 1 shows the iodine values in tap water at the different locations investigated (range $<1.0$ to $139 \mu \mathrm{g} / \mathrm{l}$ ) as well as the values of iodine in coastal sea water from Kattegat and Skagerak.

In 41 of the locations where iodine was measured in tap water, values of urinary iodine excretion collected by Munkner around 1967 (3, 4) were available. Figure 2 depicts the correlation between the present tap water iodine contents and the 24-h urinary iodine excretion measured approximately 30 years ago in young males.

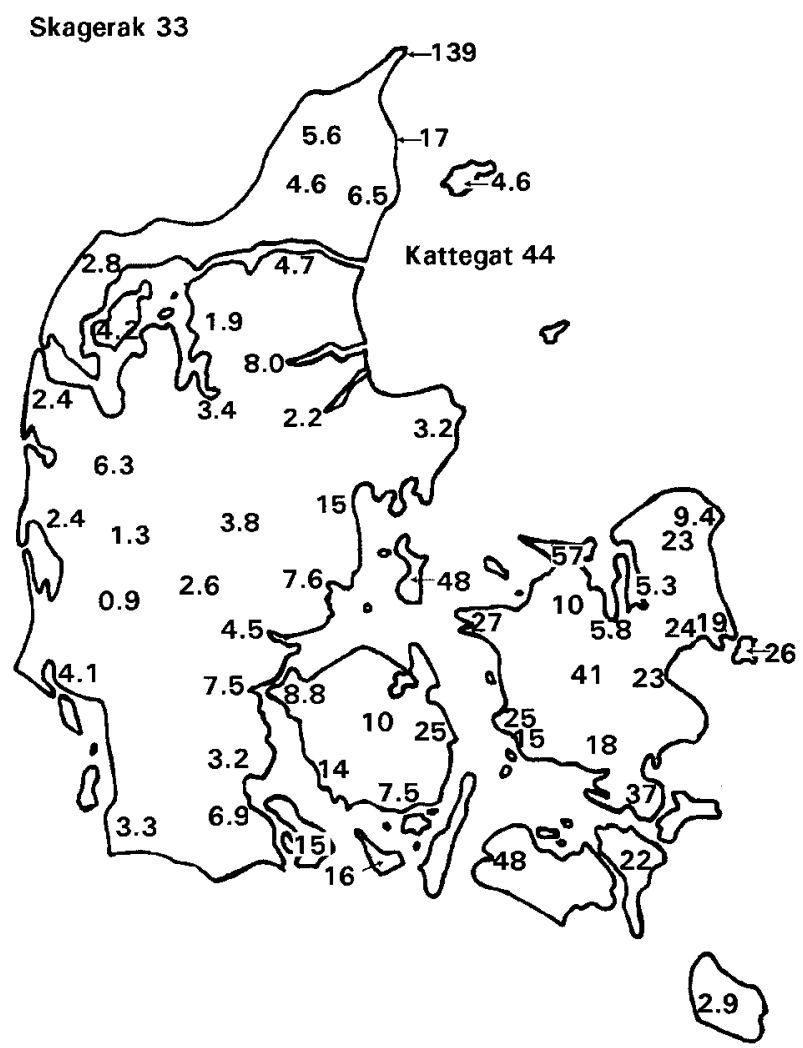

Figure $1 \mathrm{Map}$ showing the iodine content $(\mu \mathrm{g} / \mathrm{l})$ of drinking water in Denmark. lodine in sea water (Kattegat and Skagerak) was measured in water collected near the shore.

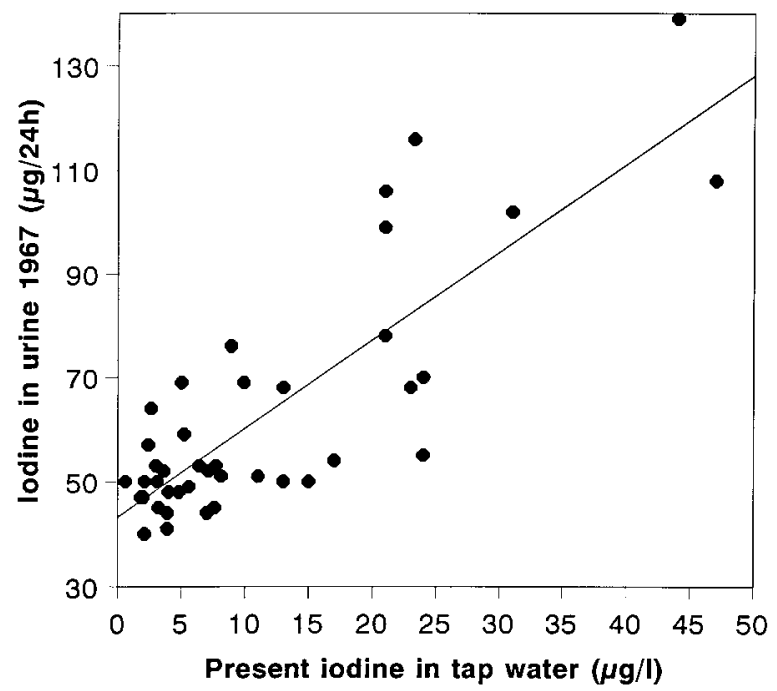

Figure 2 Correlation between the iodine content of drinking water measured in 41 Danish towns and the average 24-h urinary iodine excretion in the same towns. Urinary iodine was measured by Munkner in $1967(3,4) . P<0.001, r=0.68 ; y=1.7 x+43.2$. 
Table 1 lodine content of infant formulas.

\begin{tabular}{llc}
\hline Recomended use & \multicolumn{1}{c}{ Brand } & $\begin{array}{c}\text { lodine content } \\
(\mu \mathrm{g} / \mathrm{l}) \\
(\text { declared) }\end{array}$ \\
\hline Premature children & \multicolumn{1}{c}{$\begin{array}{c}\text { Prematil (MP) } \\
\text { Normal children }\end{array}$} & $138(100)$ \\
Regular use & Allomin (BE) & $127(100)$ \\
& Allomin, R (BE) & \\
& NAN 1 (NE) & $42(35)$ \\
& NAN 1, R (NE) & $34(40)$ \\
Babymin A (MP) & $46(34)$ \\
Against regurgitation & Babymin A, R (MP) & $69(33)$ \\
In cases of constipation & Babymælk (MD) & $52(116)$ \\
& Nidina (NE) & $58(116)$ \\
Children $>2$ months & Allomin m.laktulose (BE) & $126(80)$ \\
Children $>4$ months & Babymin B m.laktulose (MP) & $39(54)$ \\
& Babymin B m.laktulose, R (MP) & $52(35)$ \\
& Allomin m.rismel (BE) & $59(116)$ \\
& NAN 2 & $55(116)$ \\
Children with allergy & Majsvælling (BE) & $37(35)$ \\
& Majsvælling (NE) & $85(54)$ \\
& Majsvælling (MP) & $48(30)$ \\
& Nutramigen (MJ) & $41(40)$ \\
& Pregestimil (MJ) & $106(120)$ \\
& Pepdite (SC) & $65(47)$ \\
& Profylac (MC) & $58(48)$ \\
& & $75(70)$ \\
& & $55(50)$
\end{tabular}

BE, Beauvais; MC, Milco; MD, MD Foods; MJ, Mead Johnson; MP, Milupa; NE, Nestle; SC, Scientific Hospital Supplies; R, ready-made from producer.

Dry preparations were dissolved in iodine-free demineralized water before measurements.

A statistically significant correlation was found $(P<0.001, \quad r=0.68)$ with the linear regression $y=1.7 x+43.2$.

The iodine content of the eighteen formulas prepared by addition of demineralized water was $37-138 \mu \mathrm{g} / \mathrm{l}$ (median $57 \mu \mathrm{g} / \mathrm{l}$ ) (Table 1). In many preparations the values measured were quite different from the declared iodine content (Table 1). Dependent on the source of Danish water used to reconstitute the dry formulas, the final iodine content would vary from a median of $57 \mu \mathrm{g} / \mathrm{l}$ to a median of approximately $200 \mu \mathrm{g} / \mathrm{l}$. For comparison, iodine was also measured in four liquid infant formulas ready for use. The concentration varied from 34 to $69 \mu \mathrm{g} / \mathrm{l}$.

\section{Discussion}

In Denmark Munkner collected 24-h urine samples from 4580 high school boys around 1967 (3). Iodine measurements disclosed mild to moderate iodine deficiency with the lowest values in Jutland $(49 \mu \mathrm{g} /$ $24 \mathrm{~h})$ and the highest on Sealand $(74 \mu \mathrm{g} / 24 \mathrm{~h})$. Since then eating habits have changed and locally produced food represents a smaller part of the food intake. Despite this the east/west difference in urinary iodine excretion is nearly unchanged (4). A possible explanation for this might be that tap water used for drinking and food preparation contains different amounts of iodine.
Generally, water has not been considered an important source of iodine intake in Denmark.

The present study demonstrates that the iodine content of ground water varies widely and that the iodine content of water correlates to the known iodine excretion values of an area. To obtain an idea of the magnitude of the contribution of water iodine to the daily iodine intake in various regions we calculated the linear regression between the present water iodine content and the regional iodine excretion values from the previous national survey. The calculated regression corresponded to a basic urinary iodine excretion in Denmark of $43 \mu \mathrm{g} / 24 \mathrm{~h}$ if the water contained no iodine. Values above this level corresponded to an average daily intake of $1.7 \mathrm{l}$ water. Surveys of food intake in Denmark have shown that the amount of water consumed per day in coffee and tea or as drinking water by the average adult Dane is around $1.4 \mathrm{l}(8)$. To this has to be added water used in food etc. Naturally it is to be expected that differences in water iodine content might also influence the iodine content of local dairy products and vegetables grown in a greenhouse. Even if the values calculated are hypothetical and based on data obtained after an interval of nearly 30 years they suggest an important role of water iodine in iodine intake in parts of Denmark.

Preparation of coffee or tea using water with a high iodine content did not reduce the iodine concentration. It 
was slightly higher in the final preparation probably caused by a combination of release of iodine from the beans and blades and evaporation of water during preparation.

Information of the iodine content of water in different countries can be found in a number of publications. Vivanco et al. (9) studied the relationship between iodine in drinking water and the prevalence of goitre in Spain. The iodine content ranged from below $1 \mu \mathrm{g} / \mathrm{l}$ to $20 \mu \mathrm{g} / \mathrm{l}$. A highly significant correlation was found between iodine in water and the prevalence rate of goitre, with an increase in the frequency of goitre when water iodine content was below $10 \mu \mathrm{g} / \mathrm{l}$. In another study from Spain iodine in drinking water ranged from 3 to $22 \mu \mathrm{g} / \mathrm{l}$ (10). In a low iodine intake area of Turkey the iodine level of drinking water was reported to be $3 \mu \mathrm{g} / \mathrm{l}(11)$. In a study from Venezuela highly variable results were obtained ranging from $<1$ to $100 \mu \mathrm{g} / \mathrm{l}(12)$. In Thessaloniki, Greece, the tap water iodine content was $6-12 \mu \mathrm{g} / \mathrm{l}$ (13). In 21 cities in Finland the drinking water iodine content varied between 0.4 and $9.1 \mu \mathrm{g} / \mathrm{l}$ (14) and in South Baden (south-west Germany) drinking water iodine content ranging from 0.2 to $21 \mu \mathrm{g} / \mathrm{l}$ has been described (15). Hence the variation from $<1$ to $139 \mu \mathrm{g} / \mathrm{l}$ found in a relatively small area in the present study is more excessive than previously reported.

A study from Tanzania described the appearance of goitre in two villages after a shift in water supply from river water containing $28 \mu \mathrm{g} / \mathrm{l}$ iodine to underground well water containing 3-4 $\mu \mathrm{g} / \mathrm{l}$ iodine (16). A study from Australia found seasonal fluctuations in iodine content of the water supply $(3-10 \mu \mathrm{g} / \mathrm{l})$ correlating to fluctuations in goitre frequency. The variations were possibly due to dilution of water reservoirs with melted snow at spring time (17).

Iodine in drinking water has been used as an indicator of the 'iodine state' of an area (18). Obviously iodine in drinking water may also be a major direct source of iodine intake, which may determine regional variations in iodine intake levels. The present study has demonstrated this in Denmark. At the high end of the spectrum is a report from central China where excessive iodine intake leading to endemic goiter was caused by a water iodine content of $462 \mu \mathrm{g} / \mathrm{l}$ (19).

A consequence of the differences observed is that the final iodine content of infant formulas prepared using tap water may vary widely dependent on the source of water. In Denmark the iodine content of the final preparation might be much less or it might follow the latest recommended iodine content of $200 \mu \mathrm{g} / \mathrm{l}(20)$. Changes in water supply as well as changes in water purification procedures may be of importance for the population iodine intake level - and hence for the occurrence of thyroid disorders.

\section{References}

1 Laurberg P, Pedersen KM, Vestergaard H \& Sigurdsson G. High incidence of multinodular toxic goitre in the elderly population in a low iodine intake area vs high incidence of Graves' disease in the young in a high iodine intake area: comparative surveys of thyrotoxicosis epidemiology in East Jutland Denmark and Iceland. Journal of Internal Medicine 1991229 415-420.

2 Laurberg P, Pedersen KM, Hreidarsson A, Sigfusson N, Iversen E \& Knudsen PR. Iodine intake and the pattern of thyroid disorders: a comparative epidemiological study of thyroid abnormalities in the elderly in Iceland and in Jutland, Denmark. Journal of Clinical Endocrinology and Metabolism 199883 765-769.

3 Munkner T. Urinary excretion of 127-iodine in the Danish population. Scandinavian Journal of Clinical and Laboratory Investigation 1969 (Suppl 110) 134.

4 Pedersen KM, Nøhr SB \& Laurberg P. Jodindtagelse i Danmark. Ugeskrift for Lager $19971592201-2206$.

5 Ares S, Quero J, Durán S, Presas MJ, Herruzo R \& de Escobar GM. Iodine content of infant formulas and iodine intake of premature babies: high risk of iodine deficiency. Archives of Disease in Childhood 199471 F184-191.

6 Wilson B \& van Zyl A. The estimation of iodine in thyroidal amino acids by alkaline ashing. South African Journal of Medical Sciences $19673270-82$.

7 Laurberg P. Thyroxine and 3,5,3'triiodothyronine content of thyroglobulin in thyroid needle aspirates in hyperthyroidism and hypothyroidism. Journal of Clinical Endocrinology and Metabolism $198764969-974$.

8 Andersen NL, Fagt S, Groth MV, Hartkopp HB, Møller A, Ovesen L et al. Danskernes kostvaner 1995. Levnedsmiddelstyrelsen 1996.

9 Vivanco F, Palacios JM, Ramos F, Busturia MA \& Muro A. El bocio endemico en Espana. Revista Clinica Espanola 1971123 425432.

10 Gonzalez AL, Suarez-Varela MMM, Salinas MH, Valls TF, Castello LS \& Greus PC. Niveles de iodo en las aguas de consumo publico en la provincia de Valencia. Revista de Sanidad e Higiene Pública 198963 35-40.

11 Özbakir Ö, Dogukan A \& Kelestimur F. The prevalence of thyroid dysfunction among elderly subjects in an endemic goiter area of central Anatolia. Endocrine Journal 199542 713-716.

12 Venanzi F de, Pena F \& Briceno H. Contenido en Yodo del agua de bebida de la zona central norte de Venezuela. Acta Cientifica Venezolana 196718 44-49.

13 Ayiannidis A \& Voulgaropoulos AN. Catalytic determination of iodine in biological materials. Analyst $1988113153-157$.

14 Häsänen E. Iodine content of drinking water and diseases of the circulatory system. Annales Medicinae Experimentalis et Biologiae Fenniae 197048 117-121.

15 Mertz DP, Stelzer M, Heizmann M \& Koch B. Der Jodgehalt des Trinkwassers im endemischen Kropfgebiet von Südbaden. Schweizerische Medizinische Wochenschrift 1973103 550-556.

16 Amelsvoort V. Rural water-supply development and the recent appearance of endemic goitre. Tropical and Geographical Medicine 197123 304-305.

17 Hales I, Reeve T, Myhill J \& Dowda K. Goitre: seasonal fluctuations in New South Wales. Medical Journal of Australia 19691 378380.

18 Adlercreutz E. Orientiriende Untersuchung über die Verbreitung des Kropfes in Finland und über deren Zusammenhang mit dem Jodvorkommen in Wasser. Acta Medica Scandinavica 192867 325-391.

19 Li M, Liu DR, Qu CH, Zhang P, Qian Q, Zhang C et al. Endemic goitre in central China caused by excessive iodine intake. Lancet 1987 ii $257-259$.

20 Delange F, Dunn JT, Glinoer D. Specific recommendations on iodine nutrition for mothers and infants in Europe. In Iodine Deficiency in Europe: a Continuing Concern, p 478. Eds F Delange, JT Dunn \& D Glinoer. New York: Plenum Press, 1993. 